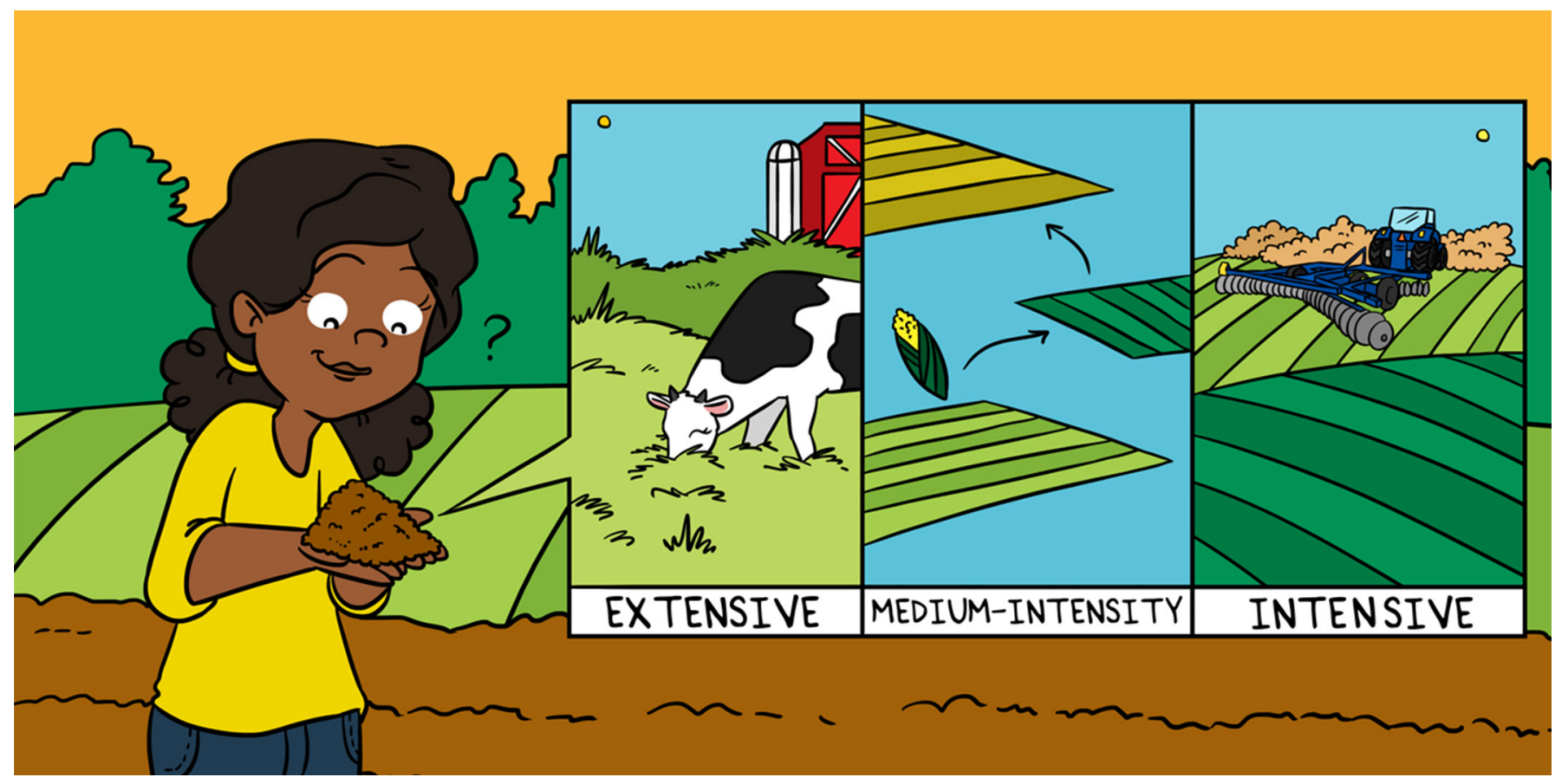

\title{
DIRT IS NOT DEAD: HOW LAND USE AFFECTS THE LIVING SOIL
}

\author{
Jes Hines ${ }^{1,2^{*}}$ and Franciska T. de Vries ${ }^{3}$ \\ ${ }^{1}$ German Centre for Integrative Biodiversity Research (iDiv) Jena-Halle-Leipzig, Leipzig, Germany \\ ${ }^{2}$ Institute of Biology, Leipzig Universität, Leipzig, Germany \\ 3 Institute for Biodiversity and Ecosystem Dynamics, University of Amsterdam, Amsterdam, Netherlands
}

\section{YOUNG REVIEWER:}

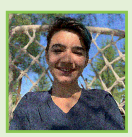

KONSTANTIN

AGE: 14
Humans use land to grow crops for food, and the farming methods we use can influence the organisms that live in the soil. Soil organisms do important work, like decomposing organic matter and releasing nutrients for plant growth. By adding more pesticides and fertilizers to farmland, we can produce more crops in a smaller space. But those methods can also harm soil organisms and the work that they do. In contrast, we can use gentler methods to grow crops, which are better for soil animals, but those methods require more land. People in all countries need food from crops to live healthy lives. Because we all share one land surface, when we decide how to use land, we need to remember how agriculture influences soil animals. 
Figure 1

The soil food web is composed of many kinds of soil organisms:

(1) bacteria, (2) fungi,

(3) arbuscular

mycorrhizal fungi, (4)

protozoans, (5)

bacteria-feeding

nematodes, (6)

fungal-feeding

nematodes, (7)

root-feeding

nematodes, (8)

collembolans, (9)

predatory nematode,

and (10) predatory

mites. Arrows point

from the organisms

that are eaten to the

organisms that eats

them. Interaction

pathways form three

main energy channels:

bacteria-based channel

(orange arrows),

fungal-based channel

(yellow arrows), and

root-based channel

(green arrows). The

magnifying glass shows

that nutrients and

energy flow through

each soil organism

when it eats

and respires.

\section{SOIL ORGANISMS}

All of the types of life forms that live below ground. This includes single celled organisms like bacteria, and multi-cellular organisms like earthworms, protozoa, nematodes, and mites.

\section{ECOSYSTEM}

\section{SERVICES}

The important things environments do for people. In soils ecosystems, examples include recycling nutrients, retaining and draining water, and mixing organic matter.

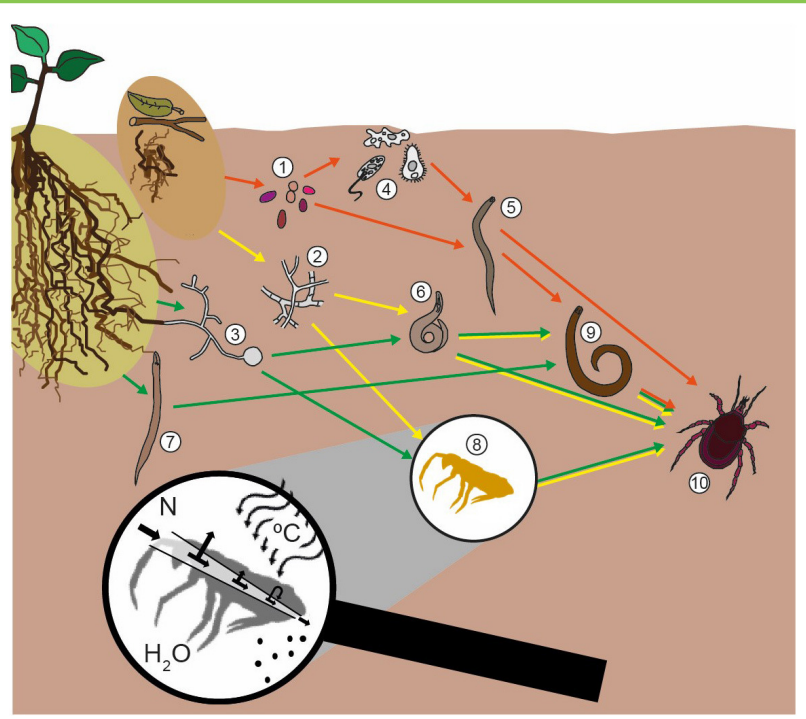

Figure 1

\subsection{BILLION PEOPLE, AND COUNTING, EAT FOOD THAT GROWS IN SOIL}

There are 7.8 billion people and all of them need to eat healthy food. Vegetables and other crops are part of a healthy diet. But producing food for so many people comes with a cost to the environment. First, we need enough farmland and then we need farming practices that keep the environment healthy. The organisms that live in soil can tell us if our farming practices are good or bad for the environment.

In the soil, there are billions of organisms, such as bacteria, fungi, nematodes, and isopods that live in soil (Figure 1). They all eat, and grow, and use oxygen and release carbon dioxide, just like we do. When soil organisms carry out these life processes, they release nutrients from their food that are useful for plant growth (Figure 1, inset). They also mix organic matter (i.e., dead plants and organisms) throughout the soil. They improve the structure of the soil, which improves water availability for plants. Soil organisms supply the resources that help plants grow the food that humans like to eat. Soils provide important ecosystem services, such as water filtration and nutrient recycling, that help keep humans alive and healthy.

\section{SOIL ORGANISMS FORM A FOOD WEB UNDER YOUR FEET}

The organisms in the soil do not work alone; they are connected with each other in a network of interactions called the soil food web. Changes in the abundance of one species can affect the abundance of their predators and prey, in a chain of interactions called an energy channel (Figure 1). Soil food webs have three main energy channels: one fueled by bacteria, another fueled by fungi, and a third fueled by 
Figure 2

Three common ways that natural

environments are used.

Extensive land use does not involve much plowing and harvesting or the addition of lots

of fertilizers and

pesticides, and it

produces diverse

ecosystem services.

Medium-intensity land

use needs some

plowing and harvesting and yields intermediate harvests. High-intensity land use requires lots of work plowing and harvesting, as well as lots of chemical use, to produce a lot of crops from a smaller area. In high-intensity land use, some ecosystem services are reduced in favor of high-output of crop production.

\section{SOIL FOOD WEB}

The network of feeding interactions among soil organisms. The interactions start from three main resources (roots, fungi, bacteria) that form

energy channels.

\section{TILLING}

Preparing soil for agriculture by plowing or digging. Tilling buries weeds and makes it easier for crop roots to enter the soil.

\section{LAND USE}

How the natural environment is managed and modified Examples in text include Intensive land use, extensive land use, and natural areas.

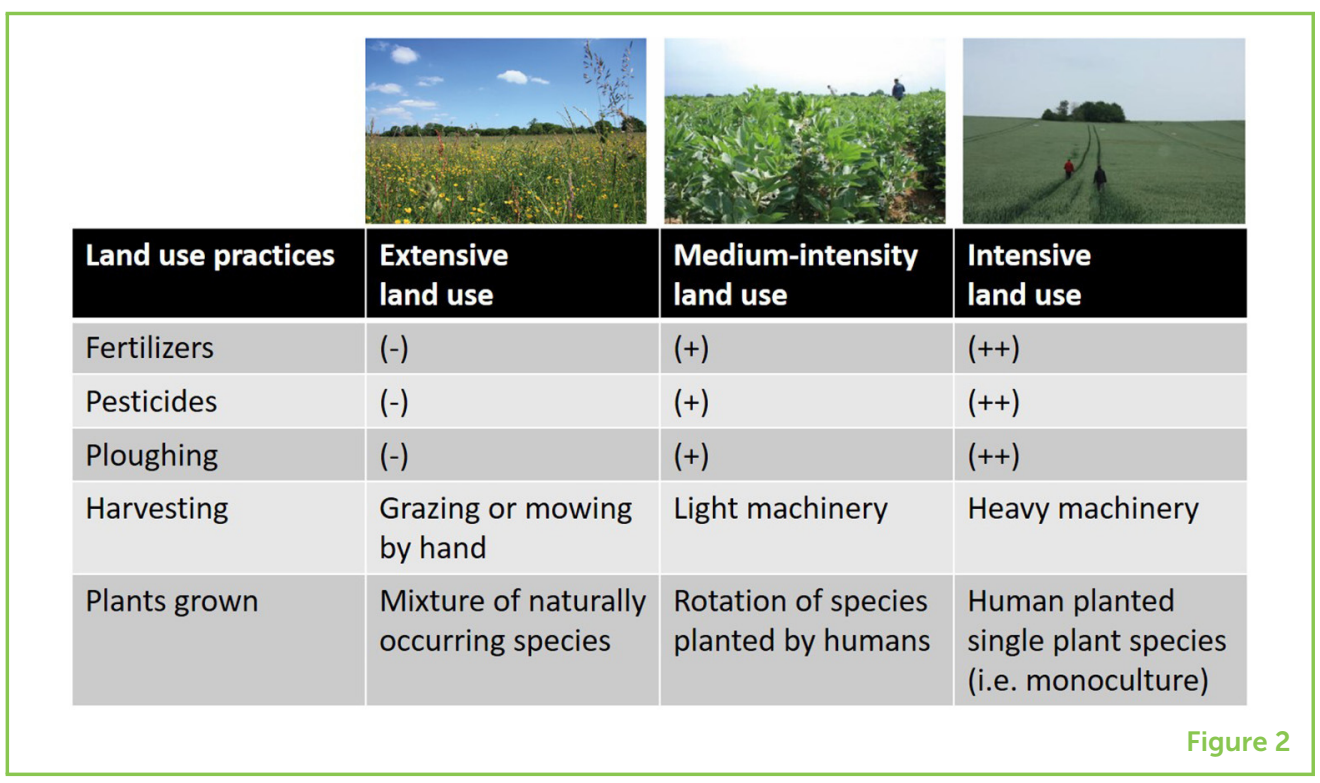

plant roots. Bacteria and fungi eat organic matter, such as dead roots and leaves, and later they are eaten by other organisms. There are also organisms that feed directly on living roots, such as root-eating nematodes (tiny worms), which are also eaten by other animals. When humans use the land in a way that disrupts these energy channels (such as by tilling the soil or adding fertilizers), they may alter the ability of soil food webs to provide their usual ecosystem services. But how many species are affected by humans and how strong is our effect on the processes soil organisms normally perform?

\section{AN EXPERIMENT TESTING THE EFFECTS OF LAND USE ON SOIL FOOD WEBS}

Scientists hypothesized that different types of land use would affect the structure of the soil food webs (Figure 2) [1]. They thought that intensive land use, such as tilling the land, would reduce the number of soil organisms and limit the ecosystem services provided by soils [1]. Scientists also thought that soil organisms would be more abundant when farmers applied extensive land use practices (such as hay meadows and pasture). In extensive land use, there is less plowing and less fertilizer added, but more land area is needed to produce the same amount of food. They thought that soil organisms would do best in natural grasslands, where farmers do not use the land to grow crops [1]

With the goal of using sites exposed to a broad range of environmental conditions (temperature, precipitation, soil texture, etc.), a team of scientists went to four countries across Europe: Sweden, Czechia, United Kingdom, and Greece. In each country, they went to sites with three types of land use: high-intensity agriculture, medium-intensity agriculture, and natural grasslands [1] (Figure 2). At 
each site, they measured a variety of soil organisms, including fungi, bacteria, protozoa, nematodes, earthworms, enchytraeids, mites, and collembolans. To find out how the ecosystem services differed between the land uses, they also measured some of the important processes performed by soil organisms.

\section{INTENSIVE FARMING REDUCES BIODIVERSITY IN THE SOIL}

The scientists found that the type of land use was important for the numbers and types of organisms that they found in the soil. They found that more intensive land use reduced the biodiversity of the soil food web: there were fewer groups of organisms present, and within these groups, there were also fewer species [2]. They also found that the total weight of most groups of soil organisms was lower where there was high- and medium-intensity land use. The organisms that are fueled by plant roots were the most reduced, and organisms that eat bacteria and fungi were affected less. This is probably because tilling the soil has strong effects on plant roots in medium- and high-intensity land use, which has extended effects on the organisms that are fueled by plant roots. But how much of the change was due to the direct effects of the tilling on the soil, and how much was due to changes in the soil food webs?

\section{PROCESSES CARRIED OUT BY SOIL ORGANISMS}

To evaluate the question above, the scientists looked at relationships between groups of soil organisms and the processes that these organisms carry out. The scientists focused on two processes: respiration and the cycling of nitrogen. When we are talking about tiny organisms, respiration is the name of the process that uses oxygen and releases carbon dioxide, to produce the energy that the organisms need to grow and perform their functions. Nitrogen is an essential element for all life, including plants. It cycles through the environment in several steps. Mineralization is the process by which nitrogen is released from organisms into the soil (Figure 3), usually when they decay. Nitrogen in the soil can be lost through leaching, which means being flushed out of the soil by water, or by denitrification, in which the nitrogen is turned into a gas called nitrous oxide $\left(\mathrm{NO}_{2}\right)$ produced by bacteria and escapes from the soil into the atmosphere.

\section{NATURAL GRASSLANDS ENHANCE SOIL RESPIRATION}

First, scientists found that the respiration of soil organisms was higher in natural grasslands and where there were more earthworms in the soil. Earthworms mix the soil, and by doing this, they stimulate the activity of other soil organisms. Just like us, when soil organisms 
Figure 3

Nitrogen is transformed by soil food webs so that it can move through plants, water, or air. Soil organic matter (dead plants and animals) is mineralized to inorganic nitrogen by the feeding activity of soil organisms. Inorganic nitrogen in soil can be taken up by plants and fungi, or it can be lost from the soil by either leaching into ground water or by conversion to $\mathrm{N}_{2} \mathrm{O}$ gas by bacteria, in a process called denitrification.

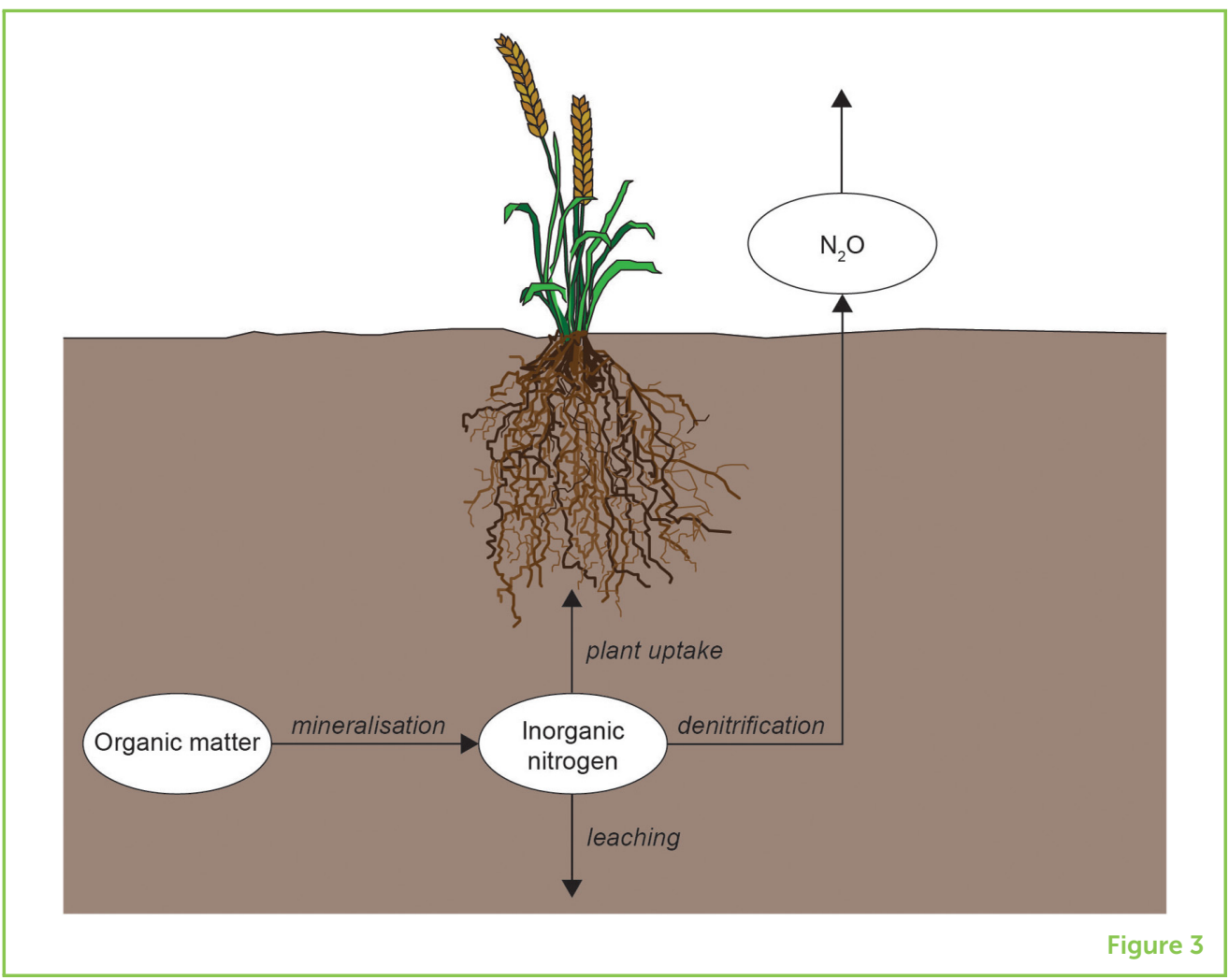

become more active, they need to eat more and respire more. When there is more organic matter available as food, there will be a greater number of active soil organisms. Because natural grasslands have higher organic matter than the fields used for medium- and high-intensity agriculture, respiration was higher in these sites.

\section{MORE NITROGEN FLOWS INTO AND OUT OF INTENSIVELY MANAGED FARMS}

When scientists looked at the cycling of nitrogen, they found that nitrogen mineralization was higher in food webs with a stronger bacterial energy channel (see soil food web in glossary). Bacteria are often very abundant in areas with intensive land use, where they grow quickly and die quickly, releasing the nitrogen from their tissues into the soil.

After they measured the mineralized nitrogen that was released into the soil, the scientists wanted to know how land use affected where the nitrogen went next. They found that, in areas with less intensive land use where there were a lot of arbuscular mycorrhizal fungi, there was less leaching of nitrogen into the water, meaning that more nitrogen stayed in the soil where plants could use it. Farmers want to limit the amount of nitrogen leaching, so that most of the nitrogen can be used by crop plants instead of flowing out of the fields. Arbuscular mycorrhizal fungi are a special group of fungi that attach to plant roots 
and help the plant take up nutrients, including nitrogen. These fungi might take up nitrogen from the soil and prevent it from being lost through leaching. So, the presence of arbuscular mycorrhizal fungi could be a good indicator of reduced leaching across different types of land use.

To evaluate the amount of denitrification, scientists measured the concentration of nitrous oxide gas $\left(\mathrm{N}_{2} \mathrm{O}\right)$. They found lower $\mathrm{N}_{2} \mathrm{O}$ concentrations where there was an increased number of flagellates-tiny creatures that use a tail to propel themselves forward in the water that is within the soil and that eat bacteria. Importantly, denitrification is not actually done by flagellates, but by a specific group of bacteria. Because flagellate increased in areas where denitrifying bacteria were not abundant, we may be able to use flagellate abundance as an important indicator of other processes (e.g., denitrification) and soil organisms (e.g., denitrifying bacteria). Understanding what is happening in soil food webs with low concentrations of denitrifying bacteria is important because, when nitrogen leaves the soil as $\mathrm{N}_{2} \mathrm{O}$, it can make climate change worse. $\mathrm{N}_{2} \mathrm{O}$ is a greenhouse gas that is 314 times stronger than $\mathrm{CO}_{2}$ !

\section{INCREASE SOIL BIODIVERSITY TO MINIMIZE THE IMPACTS OF INTENSIVE FARMING}

The question of the "right" way to use land to grow vegetables and other crops is an ongoing scientific and social debate. How can humans produce healthy and enough food for billions of people with the minimal impact to the planet? Scientists are learning that soil organisms are sensitive to changes humans make to the environment. Farming practices do not just influence individual organisms, they influence a complex network of species interactions. Changes in this interaction network affect how energy flows through an ecosystem, which nutrients are retained, which nutrients are lost, and how farmers will have to rely on fertilizers and pesticides. While intensive land use takes up less land area, which is positive, it also causes many negative impacts since it decreases soil biodiversity and increases losses of nutrients and carbon. In opposition, lower intensity land use produces fewer crops but is more environmentally-friendly. So, one solution is to restore soil biodiversity in intensive land use areas to make them less dependent on fertilizers and pesticides, which is good for the environment and therefore for humans. So, if you have the possibility to grow your own vegetables you will be protecting the environment because you will not be producing them through intensive agriculture practices. If you cannot plant your vegetables, you can still protect the environment if you can buy vegetables and other crops that are not produced in intensive farmland. Little by little we can make our planet healthier and healthier. 


\section{ORIGINAL SOURCE ARTICLE}

de Vries, F. T., Thébault, E., Liiri, M., Birkhofer, K., Tsiafouli, M. A., Bjørnlund, L., et al. 2013. Soil food web properties explain ecosystem services across European land use systems. Proc. Natl. Acad. Sci. U.S.A. 110:14296-301. doi: 10.1073/pnas.1305198110

\section{REFERENCES}

1. de Vries, F. T., Thébault, E., Liiri, M., Birkhofer, K., Tsiafouli, M. A., Bjørnlund, L., et al. 2013. Soil food web properties explain ecosystem services across European land use systems. Proc. Natl. Acad. Sci. U.S.A. 110:14296-301. doi: 10.1073/ pnas. 1305198110

2. Tsiafouli, M. A., Thébault, E., Sgardelis, S. P., de Ruiter, P. C., van der Putten, W. H., Birkhofer, K., et al. 2015. Intensive agriculture reduces soil biodiversity across Europe. Glob. Change Biol. 21:973-85. doi: 10.1111/gcb.12752

SUBMITTED: 06 April 2020; ACCEPTED: 13 October 2020;

PUBLISHED ONLINE: 09 November 2020.

EDITED BY: Malte Jochum, German Centre for Integrative Biodiversity Research (iDiv), Germany

CITATION: Hines J and de Vries FT (2020) Dirt Is Not Dead: How Land Use Affects the Living Soil. Front. Young Minds 8:549486. doi: 10.3389/frym.2020.549486

CONFLICT OF INTEREST: The authors declare that the research was conducted in the absence of any commercial or financial relationships that could be construed as a potential conflict of interest.

COPYRIGHT @ 2020 Hines and de Vries. This is an open-access article distributed under the terms of the Creative Commons Attribution License (CC BY). The use, distribution or reproduction in other forums is permitted, provided the original author(s) and the copyright owner(s) are credited and that the original publication in this journal is cited, in accordance with accepted academic practice. No use, distribution or reproduction is permitted which does not comply with these terms.

\section{YOUNG REVIEWER}

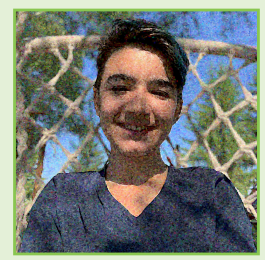

\section{KONSTANTIN, AGE: 14}

$\mathrm{Hi}$ I am Konstantin, your nearby Young Mind! I am from Rousse, Bulgaria and since I was little I had questions like: what is the point in recycling etc. Now, as an adolescent, I really got into ecology and decided to help bring awareness of some of the problems in our world has like the air pollution, species extinction, and deforestation. If I, an ordinary student, can make a difference you can too-so what are you waiting for my young reader! 


\section{AUTHORS}

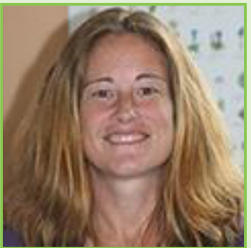

\section{JES HINES}

Jes is an ecologist working at the German Centre for Integrative Biodiversity Research (iDiv). Her research focuses on how biodiversity responds to changes in the environment. She is interested in how complex systems grow and how species influence the flux of nutrients, energy, and information through ecosystems. *jessica.hines@idiv.de

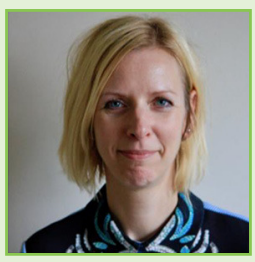

\section{FRANCISKA T. DE VRIES}

Franciska de Vries is a professor at the University of Amsterdam. Her research focusses on understanding how interactions between plants and soil microbes respond to climate change, and how this affects the functioning of the ecosystem. 